\title{
Kan epigenetiske mekanismer skru fedmeutvikling av eller på?
}

\section{Studier av mus og mennesker tyder på at overvekt kan utvikles ved en} enten-eller-mekanisme.

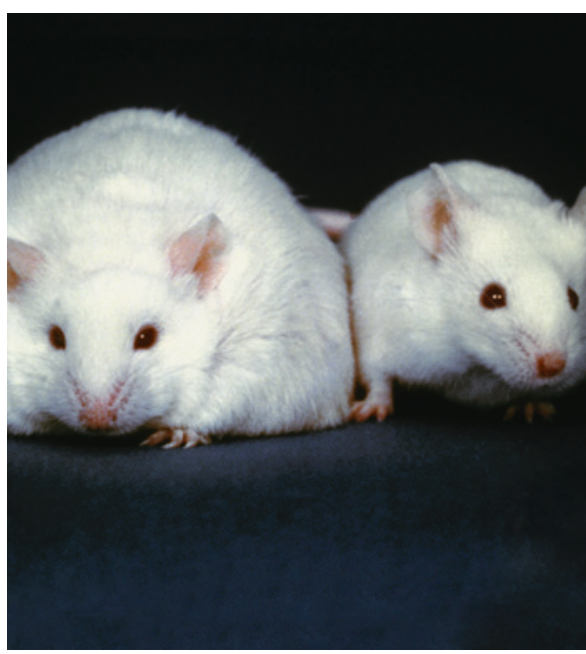

Illustrasjonsfoto: Science Photo Library
Genetisk identiske mus med en spesiell mutasjon kan utvikle seg helt forskjellig hva gjelder kroppsvekt (1). De blir normalt slanke eller feite - uten jevn overgang mellom de to fenotypene, altså en topuklet fordeling. Fedmen berodde på epigenetisk nedregulering av en klynge av gener. Barn med spontant lav transkripsjonsaktivitet i det aktuelle genet kunne også bli enten overvektige eller normalvektige, men bare de overvektige hadde den samme nedreguleringen av genklyngen som musene hadde. Analyser av fettvev hos eneggede tvillinger, der den ene var overvektig og den andre var normalvektig, viste samme type resultat - noe som tyder på at epigenetiske mekanismer ligger bak.

- Denne studien er veldig interessant, siden tilsynelatende genetisk identiske mus utvikler seg til to ulike, nokså distinkte fenotyper, sier professor Dag Erik Undlien ved Avdeling for medisinsk genetikk, Universitetet i Oslo. - Disse fenotypene samsvarer med spesifikke mønstre av genuttrykk uten at musene er blitt systematisk forskjellsbehandlet. Det er overraskende funn.
- Det finnes holdepunkter for at de samme epigenetiske forskjellene kan være med på å forklare fedmeutvikling hos mennesker. Dette gjør at studien kan få stor betydning for vår forståelse av fedmeutvikling, sier Undlien.

- Men studien reiser like mange nye spørsmål som den gir svar, slik det ofte er med god forskning. Forfatterne sannsynliggjør at det kan være en eller flere miljøfaktorer i fosterlivet eller i tidlig barndom som fungerer som «brytere» som er med på å bestemme hvorvidt man får en epigenetisk fedmeprofil eller ikke. Identifisering av slike miljøfaktorer og forståelse av hvordan de virker, kan tenkes å gi helt nye muligheter for å forebygge fedme, sier Undlien.

\section{Haakon B. Benestad}

Universitetet i Oslo

Litteratur

1. Dalgaard K, Landgraf K, Heyne S et al. Trim28 haploinsufficiency triggers bi-stable epigenetic obesity. Cell 2016; 164: 353-64.

\section{Frukt ga friskere hjerter}

\section{Personer som spiste frukt hver dag, hadde lavere risiko for å få hjerte- infarkt enn dem som var mindre ivrige fruktknaskere.}

I en observasjonsstudie, foretatt i Kina, ble over 500000 personer stilt detaljerte spørsmål om matvaner, røyking, alkohol, fysisk aktivitet, tidligere sykdommer og utdanningsnivå (1). De ble veid og målt og fikk målt blodtrykk og blodglukose. I løpet av oppfølgingsperioden på til sammen 3,2 millioner personår døde over 5100 av kardiovaskulær sykdom, over 2500 fikk hjerteinfarkt, over 14500 fikk iskemisk hjerneslag og over 3500 fikk hjerneblødning.

De som opplyste at de spiste frukt hver dag, hadde lavere systolisk blodtrykk og lavere blodglukose enn dem som opplyste at de spiste frukt sjelden eller aldri. Justert hasardratio for kardiovaskulær død var 0,60 blant fruktspiserne versus dem som spiste frukt sjelden $(95 \%$ KI $0,54-0,67)$. For hjerteinfarkt, iskemisk hjerneslag og hjerneblødning var justert hasardratio henholdsvis 0,66 $(0,58-0,75), 0,75(0,72-0,79)$ og $0,64(95 \%$ KI $0,56-0,74)$.

- Denne studien nærmest dobler kunnskapsgrunnlaget vårt om sammenhengen mellom hjerte- og karsykdom og fruktspising, sier Serena Tonstad, overlege ved Seksjon for preventiv kardiologi ved Oslo universitets- sykehus. - Man kan jo ikke trekke slutninger om kausalitet ut fra observasjonsstudier, men den beskyttende effekten av fruktspising i studien var sterkere enn vi hadde forventet, og den inverse sammenhengen mellom fruktspising og hjerneblødning var overraskende, sier hun.

- Resultatene bekrefter at retningslinjer for forebygging og behandling av hjerte- og karsykdom og diabetes fortsatt må ha anbefalinger om daglig inntak av frukt. Frukt er en utmerket kilde til vitaminer og fytokjemikalier. Frukt kan tilfredsstille appetittregulerende mekanismer og stimulere belønningssentre $i$ hjernen og dermed redusere behovet for mindre sunne alternativer slik som kaker, brus og smågodt. Vi anbefaler våre pasienter med risiko for hjertesykdom, diabetes eller fedme alltid å ha oppskåret frukt tilgjengelig, sier Tonstad.

\section{Martine Rostadmo}

Tidsskriftet

\section{Litteratur}

1. Du H, Li L, Bennett D et al. Fresh fruit consumption and major cardiovascular disease in China. N Engl J Med 2016; 374: 1332-43.

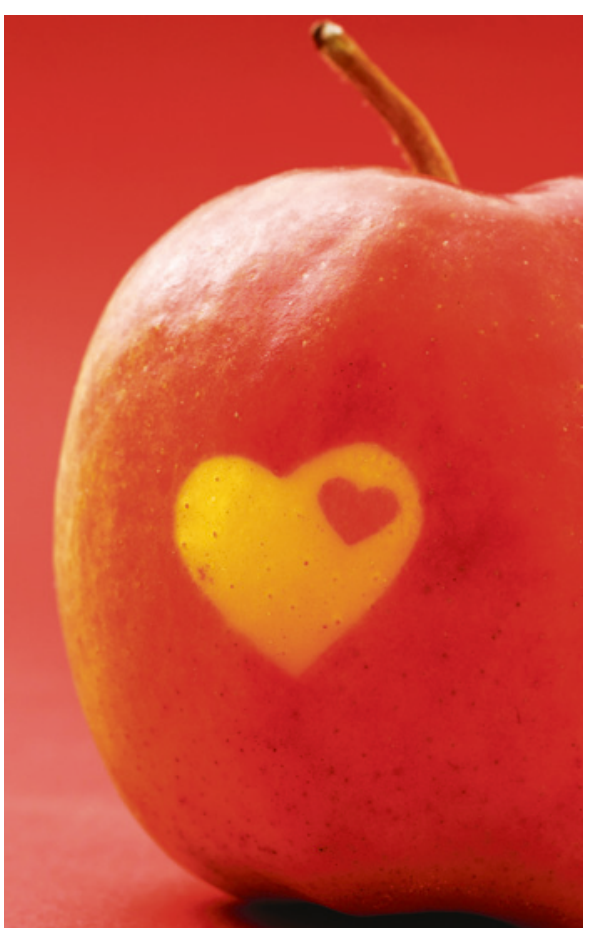

Illustrasjonsfoto: NTB scanpix 